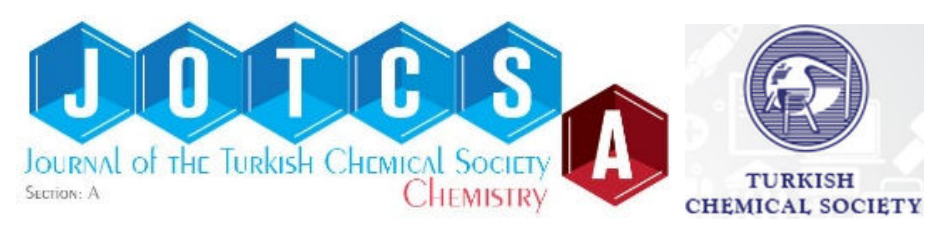

(This article was presented to the 28th National Chemistry Congress and submitted to JOTCSA as a full manuscript)

\title{
Influence of Aluminum Concentration on the Electrical and Optical Properties of ZnO Thin Films
}

\author{
Ebru Gungor* and Tayyar Gungor \\ Mehmet Akif Ersoy University, 15030 Burdur, Turkey
}

\begin{abstract}
Al}: \mathrm{ZnO}(\mathrm{AZO})$ thin films having with different Al concentrations were deposited on glass substrates by a sol-gel technique. The effects of Al doping on the structural, optical, and electrical properties of $\mathrm{Al}: \mathrm{ZnO}$ were investigated using with XRD, optical transmittance, and sheet resistance measurements. The concentration of zinc acetate was $0.1 \mathrm{M}$. Al content in the starting solution was varied from 0 to $20 \%$ as the molarity range. Optical transmittance spectra of the films in the form of Film/Glass were used to determine the film thickness and optical band gaps. The optical transmissions of Al:ZnO thin films were higher than $80 \%$ in the visible and near infrared region. The optical band gaps of Al:ZnO films decrease with increase of Al content. In order to obtain the average sheet resistance of the films the current and voltage through the probes have been measured for five different position by four-point probe method. The results showed that the sheet resistances of $\mathrm{Al}: \mathrm{ZnO}$ thin films increased with the Al concentration. Considering the film thickness and geometric factor, the electrical resistivity values were computed. It was observed that the sheet resistance of AZO films up to $10 \%$ molarity of $\mathrm{Al}$ in the starting solution increased.
\end{abstract}

Keywords: Aluminum doped zinc oxide; thin film; ultrasonic spray pyrolysis technique; electrical characterization; optical constants.

Submitted: July 09, 2016. Revised: September 23, 2016. Accepted: October 03, 2016.

Cite this: Güngör $E$, Güngör T. Influence of Aluminum Concentration on the Electrical and Optical Properties of ZnO Thin Films. JOTCSA. 2016;3(3):453-62.

DOI: $10.18596 /$ jotcsa.18812.

*Corresponding author. E-mail: egungor@mehmetakif.edu.tr. 


\section{INTRODUCTION}

$\mathrm{ZnO}$ and $\mathrm{ZnO}$-related compounds are suitable for many different applications, such as opto-electrodes, surface acoustic wave devices (SAW), and sensor materials. In order to meet these demands, various dopants such as group III-A elements of the periodic table ( $B, A l, G a, I n)$ can be used. These elements have been used to increase the electron density for conductivity of ZnO films $[1,2]$. Considering these elements' cost, nontoxic natures, good electrical conductivity, and availability in nature, Al comes to the forefront $[3,4]$. It is possible to coat the substrate surface with the Al material using different growth techniques such as sputtering, metal organic vapor deposition (MOCVD), pulsed laser deposition, and ultrasonic spray pyrolysis technique (USP). The USP technique, among the various deposition techniques, is quite simple and the required setup is economic and flexible for process modifications such as large area coating for industrial applications. Dopant-induced optical band gap shift observed in Al doped ZnO thin films prepared by USP technique. The blue shift in the optical band gap of Al:ZnO films for low Al concentrations is observed [5]. However, the optical band gap energy was decreased by doping process, which was finding in photoluminescence spectrum of Al doped $\mathrm{ZnO}$ film [6]. As seen there is a conflict about the optical band gap shifting for the Al-doped ZnO prepared by USP.

In this study, undoped and Al-doped $\mathrm{ZnO}$ polycrystalline thin films were fabricated on glass substrates by using USP system. The effects of Al doping on structural, optical, and electrical properties of $\mathrm{ZnO}$ thin films were investigated by the X-ray diffraction, optical transmittance, and sheet resistance measurements at room temperature.

\section{MATERIALS AND METHODS}

\section{Experimental details}

Undoped $\mathrm{ZnO}$ and $\mathrm{Al}$-doped $\mathrm{ZnO}$ (labeled as $\mathrm{Al}: \mathrm{ZnO}$ or $\mathrm{AZO}$ ) thin films were deposited on to ultrasonically cleaned glass substrates using the ultrasonic spray pyrolysis (USP) technique. With conventional USP technique, the substrates were fixed and precursor solution was sprayed over a hot substrate. The substrate temperature was kept at 400 ${ }^{\circ} \mathrm{C}$. The salts of zinc acetate dehydrate $\left(\mathrm{CH}_{3} \mathrm{COO}\right)_{2} .2 \mathrm{H}_{2} \mathrm{O}, 99.9 \%-$ Merck) and Al chloride hexahydrate $\left(\mathrm{AlCl}_{3} .6 \mathrm{H}_{2} \mathrm{O}, 99.9 \%\right.$-Merck) as the metal sources which were dissolved in methanol. In order to produce a clear and homogeneous solution, monoethanolamine 
(MEA) was added into the precursor solution which was stirred at $60{ }^{\circ} \mathrm{C}$ at a moderate speed for $1 \mathrm{~h}$. In the starting solutions, Al contents were changed from $2 \%$ to $\% 20$ according to Zn salt's molarity and the films were labeled as AZO1-AZO20 (Table 1). Zn content $(0.1 \mathrm{M})$ was held constant. The solution flow rate was held constant at $5 \mathrm{~mL} / \mathrm{min}$. Nozzle (100 kHz oscillator frequency) used in this study was in a downward vertical configuration. A more detailed description of the USP system were reported in previous papers [7]. X-ray diffraction (XRD) patterns were collected with a D-Max X-ray diffractometer (Rigaku International Corp. Japan) with CuK $\alpha 1_{\alpha}(\lambda=1.5405 \AA$ ) to obtain the structural information of the films. The optical measurements of the Al:ZnO thin films were carried out at room temperature using T70 Model Spectrophotometer (PG Instrument) in the wavelength range $300-900 \mathrm{~nm}$. The sheet resistance of thin films was determined using 4-point probe method.

Table 1. Calculated film thickness $t(\mathrm{~nm})$, refractive index $n$ for $390 \mathrm{~nm}$ and $700 \mathrm{~nm}$ wavelengths, and $E_{g}(\mathrm{eV})$ optical band gap values of the AZO thin films vs the molarity of $\mathrm{Al}$ in the starting solutions.

\begin{tabular}{cccccc}
\hline Sample & $\begin{array}{c}\text { Molarity of Al } \\
(\mathbf{M})\end{array}$ & $\begin{array}{c}\boldsymbol{t} \\
(\mathbf{n m})\end{array}$ & $\begin{array}{c}\boldsymbol{n} \\
(\mathbf{3 9 0 n m})\end{array}$ & $\begin{array}{c}\boldsymbol{n} \\
(\mathbf{7 0 0 n m})\end{array}$ & $\begin{array}{c}\boldsymbol{E}_{\boldsymbol{g}} \\
(\mathbf{e V})\end{array}$ \\
\hline ZO & 0.00 & 602 & 2.22 & 2.00 & 3.23 \\
AZO2 & 0.02 & 104 & 2.00 & 1.67 & 3.32 \\
AZO3 & 0.03 & 118 & 2.19 & 2.00 & 3.30 \\
AZO4 & 0.04 & 88 & 2.21 & 1.88 & 3.32 \\
AZO5 & 0.05 & 81 & 2.47 & 1.88 & 3.32 \\
AZ010 & 0.10 & 104 & 2.05 & 1.55 & 3.32 \\
AZ020 & 0.20 & 220 & 1.74 & 1.48 & 3.35 \\
\hline
\end{tabular}

\section{RESULTS AND DISCUSSION}

\section{Structural characterization}

The X-ray patterns for $\mathrm{Al}: \mathrm{ZnO}$ thin films at room temperature and reference peak positions are presented in Fig. 1. All the films were polycrystalline with a structure that belongs to the hexagonal wurtzite type that of $\mathrm{ZnO}$. It was observed that the (002) peak indicating a strong orientation along the c-axis for undoped $\mathrm{ZnO}$ film. For $\mathrm{Al}$ with $2 \%$ molarity doped ZnO film, (200) and (101) as well as (110) and (103) peaks were observed. It was difficult to detect (101), (110), and (103) peaks for the increasing Al concentration. When a small amount of Al was introduced into the $\mathrm{ZnO}$ film, Al was 
ionized into $\mathrm{Al}^{3+}$ and substitute for $\mathrm{Zn}^{2+}$ sites. The intensity of the (002) peak decreases and corresponding peak position moves to the lower angles up to $10 \%$ molarity of Al. $\mathrm{Zn}$ and $\mathrm{Al}$ have different ion size such as $0.074 \mathrm{~nm}$ and $0.054 \mathrm{~nm}$, respectively. This can cause a stress which affects to shift the peak position and change the peak characteristics (Fig 2). In the XRD patterns, it was observed that the full width half maxima values decreased. The reason of this is the increase of the crystallinity of films.



Figure 1. XRD patterns of $A Z O$ and undoped $\mathrm{ZnO}$ films. "I"indicates the reference peaks for ZnO (JCPDS file no. 03-065-3411).

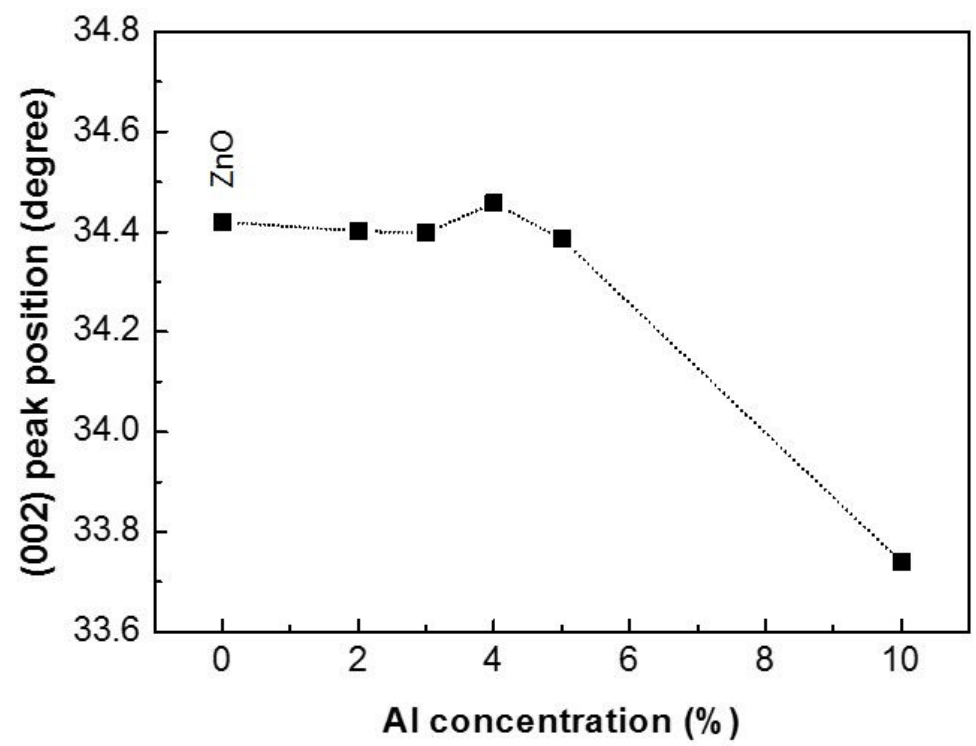

Figure 2. (002) peak position as a function of Al doping concentration. 


\section{Optical characterization}

The optical transmission spectra $T(\lambda)$ of $\mathrm{ZnO}$ and Al-doped $\mathrm{ZnO}$ thin film samples are shown in Fig 3. The optical transmission spectra were used to determination of the optical constants of the thin films. In cases where the refractive index does not change very fast with wavelength, and considering the thin film thickness, interference fringes could not be seen in the optical transmission spectrum. In this cases, one of the iterative method such as pointwise unconstrained minimization algorithm (PUMA) [8] that can be used as an alternative to the classical method developed by Swanepoel [9]. There is excellent agreement between the experimental spectra and theoretical spectra for all the samples and one of the experimental and theoretical optical transmission spectra for the $\mathrm{Al}: \mathrm{ZnO}$ thin film are shown in Fig. 4. Calculated film thickness and refractive index for $390 \mathrm{~nm}$ and 700nm are given in Table 1. The effects of Al doping into the ZnO lattice is clearly observed in the optical transmission spectra. The results showed that the optical transmittance of Al:ZnO samples in the range of $550-1100 \mathrm{~nm}$ wavelength region increases with the Al concentration except for the samples containing $2 \%$ and $3 \%$. As it is observed in the structural characterization of the films, the (002) peak intensity and its angular position changes clearly are seen in the XRD pattern for the Al concentration higher than $3 \%$. This can be associated with a refractive index, which is an important parameter.

The decrease of the refractive index that is indicating the optical transmission increases. This result is clearly observed in the optical transmission spectrum. It requires attention to calculate the band gap value using traditional methods. If the transmittance rapidly decreases in the UV region this means that absorption increases. Then the optical band gap of the film can be calculated using the Tauc relation. After Al-doped in ZnO film two different behaviors at low wavelengths in the optical transmission spectrum can be observed. In this case, the optical band gaps of the thin films can be determined using this wavelength with the relation, $E_{g}(\mathrm{eV})=1240.8 / \lambda_{\text {inf }}$. Where $\lambda_{\text {inf }}$ is the defined as the inflexion wavelength where the second derivative of the transmission curve is zero [10]. The optical band gap $\left(E_{g}\right)$ was estimated from the second derivative of the $T(\lambda)$ (Table 1). It is observed that $E_{g}$ in the undoped $\mathrm{ZnO}$ thin film is $3.23 \mathrm{eV}$ which is lower than value of bulk $\mathrm{ZnO}(3.37 \mathrm{eV})$. The change in the band gap value was observed in the AZO films prepared up to $10 \%$ molarity of Al. Then the band gap increased with doping over $10 \%$ molarity of Al. For Al doped ZnO film (AZO20) which prepared with the $20 \%$ molarity of $\mathrm{Al}$ in the starting solution, the band gap was observed as a value of $3.35 \mathrm{eV}$. Similar type of $E_{g}$ behavior have been reported for Al doped $\mathrm{ZnO}$ thin film that deposited by USP technique [11]. 


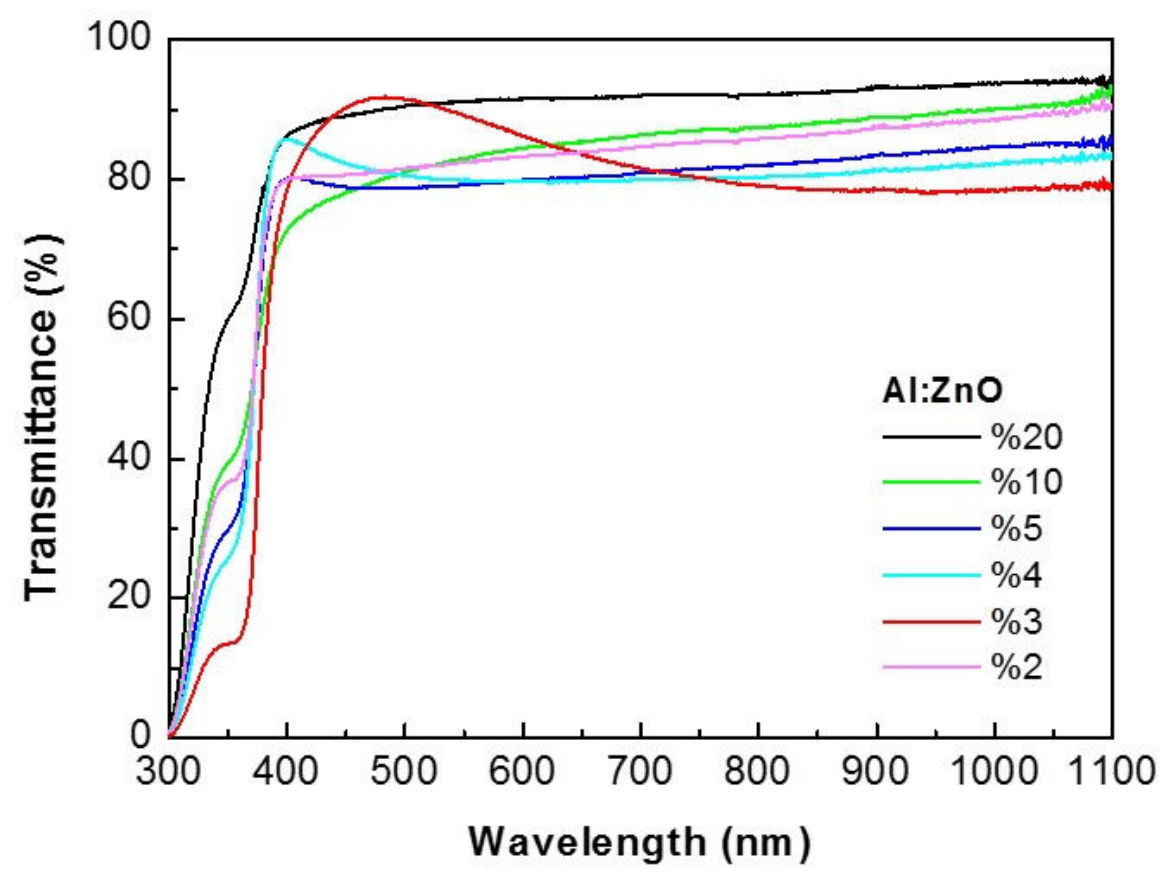

Figure 3. Optical transmittance spectra of Al:ZnO films.

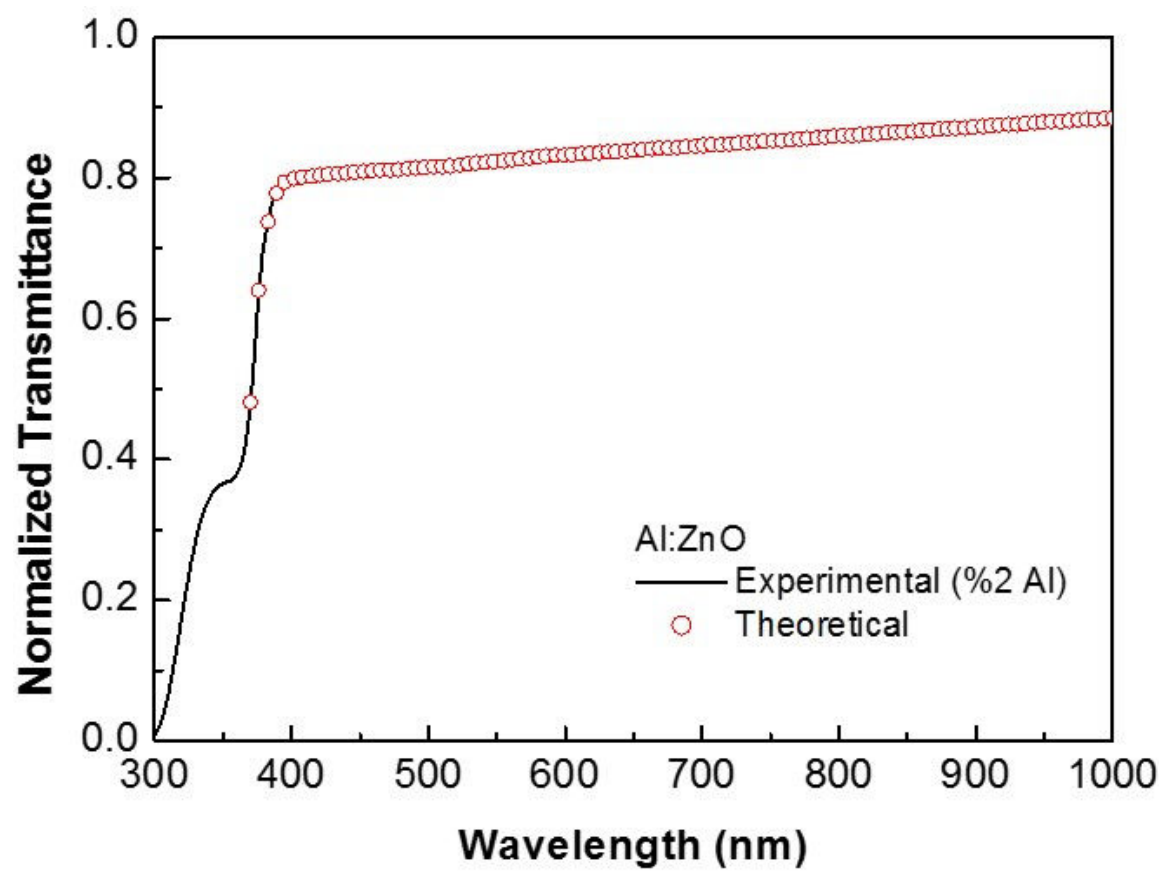

Figure 4. Experimental optical transmittance spectrum (solid line) for $2 \%$ Al molarity in starting solution for AZO2 sample: Also the theoretical optical transmission spectrum ("o" symbol) obtained using PUMA are shown for comparison.

\section{Electrical characterization}

In order to obtain the conductivity of the films, the resistance was determined by fourpoint probe method. The current and voltage through the probes have been measured for five different positions. Then the average sheet resistance obtained (Rsheet $=G F * V / I$ ). 
Where GF is the geometric factor related with sample width and inter-electrode spacing. Considering the thin film thickness and geometric factor, the electrical resistivity/conductivity was computed. The results showed that while the sheet resistance of $\mathrm{Al}: \mathrm{ZnO}$ thin film increases with the Al concentration (Fig 5) conductivity decreases with the Al concentration (Fig 6). The decrease in optical conductivity can be explained as increasing optical transmittance due to the low absorbance $(\alpha)$ of Al:ZnO thin films at low photon energies region using the relation [12] $\sigma=\alpha n c / 4 n$, where $c$ is the speed of light. In addition, the increase of Al concentration can cause some kind of neutral defect. Because of this case these neutralize Al atoms cannot contribute free electrons for the higher doping concentrations.

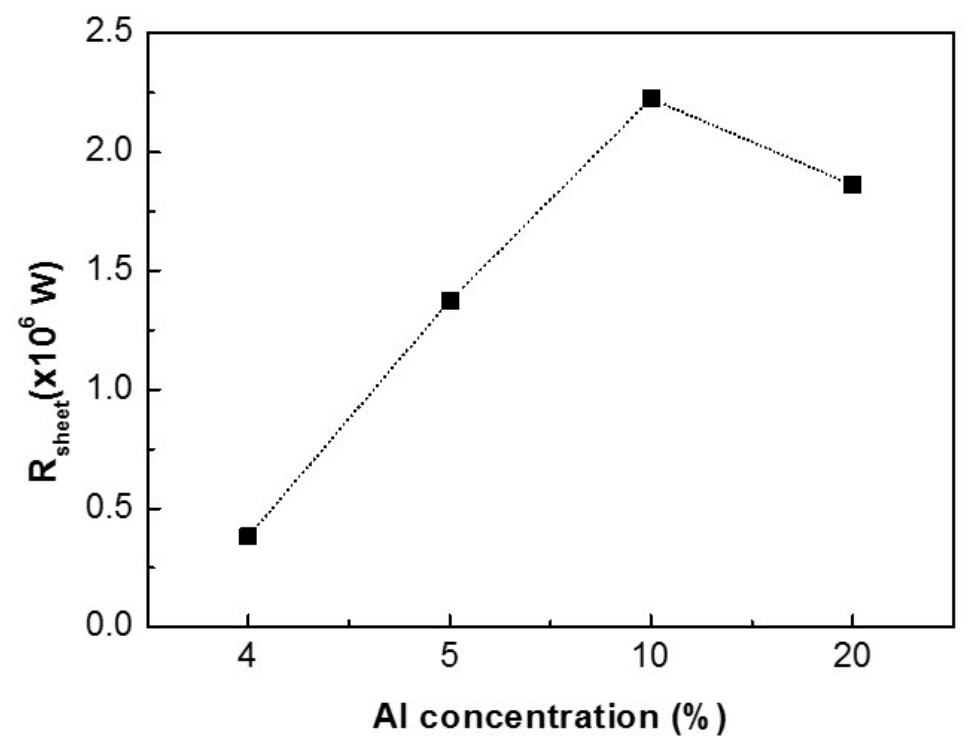

Figure 5. The sheet resistance as a function of Al concentration (\%) in the starting solution of AZO films.

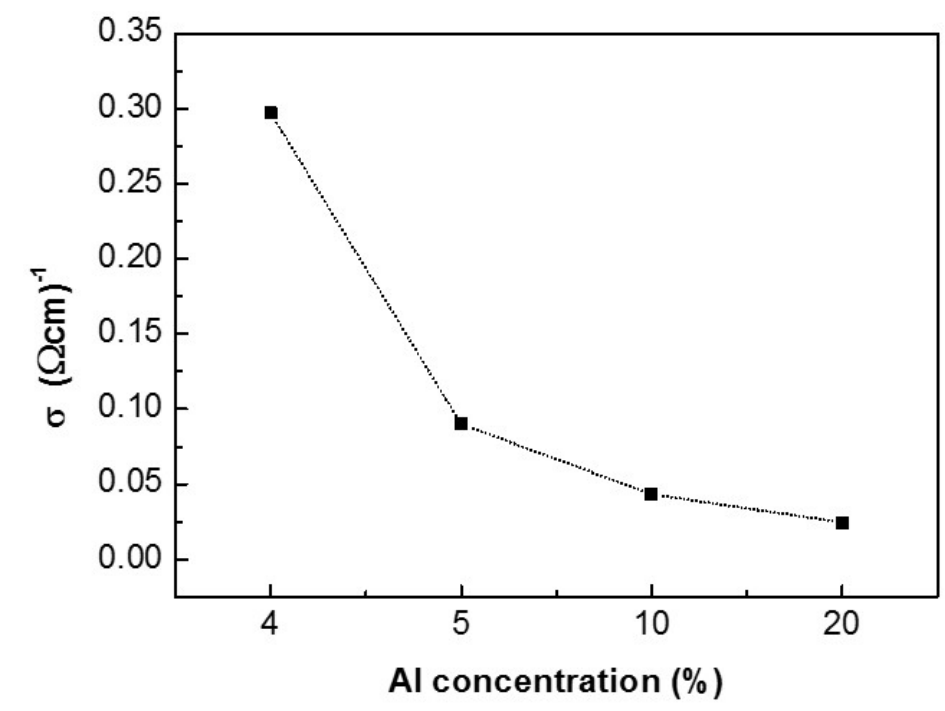

Figure 6. Electrical conductivity vs Al concentration (\%) in the starting solution of AZO films. 


\section{CONCLUSION}

In this study $\mathrm{Al}: \mathrm{ZnO}$ thin films having with Al at different concentrations were deposited on glass substrates by ultrasonic spray pyrolysis technique. The effect of doping on the crystalline structure was studied by the X-ray diffraction measurement. The wurtzite structure with preferred orientations of $\left(\begin{array}{lll}0 & 0 & 2\end{array}\right)$ retained for the Al:ZnO films. Optical transmittance spectrum of the films in the form of film/glass was used to determine the film thickness and optical band gaps. The refractive index values decrease when Al concentration increased which makes the increase in the transmittance for the doped films. The optical transmission of Al:ZnO/Glass samples was higher than $80 \%$ in the visible and near infrared region. After Al-doped in $\mathrm{ZnO}$ film, the shoulder observed at lower wavelengths in the transmission spectrum with increasing amounts of $\mathrm{Al}$, is a sign that the band gap increases. The optical band gap energy obtained from second derivative of the transmission curve was increased by Al doping. So, the sheet resistance of $\mathrm{Al}: \mathrm{ZnO} / \mathrm{Glass}$ samples increases with the Al concentration. Considering the film thickness and geometric factor, the electrical conductivity was computed and the results showed that the low Al concentration values had more important role for the electrical properties of AZO films. In other words, the increasing of the Al content will be effective on the neutral defects of semiconductor structure. Structural changes has been proved by XRD measurements for the $\mathrm{ZnO}$ films including the more Al concentration. This case means that the electrical conductivity decreases when Al doping is high.

\section{ACKNOWLEDGMENTS}

This study was supported by TUBITAK with the number of project $16 \mathrm{F046}$ and the Scientific Research Unit of Mehmet Akif Ersoy University with number of projects 110NAP-10, 100-NAP-10,172-NAP-13, 173-NAP-13, 0324-NAP-16 and 0356-NAP-16.

\section{REFERENCES}

[1] Minami T, Sato H, Nanto H, Takata S, Highly Conductive and Transparent Silicon Doped Zinc Oxide Thin Films Prepared by RF Magnetron Sputtering. Jpn J Appl Phys. 1986;25:9-L776. http://stacks.iop.org/1347-4065/25/i=9A/a =L776. 
[2] Kobayashi K, Maeda T, Matsushima S, Okada G, Mechanism of Photoinduced Charge Transfer of Cu-Doped ZnO Film in Strong Electric Field. J Mater Sci. 1992;32:9R-3854. http://stacks.iop.org/1347-4065/32/i=9R/a=3854.

[3] Li Q. H, Zhu D, Liu W, Liu Y, Ma X. C, Optical properties of Al-doped ZnO thin films by ellipsometry. Appl. Surface Sci. 2008, 254, 2922-2926. DOI:10.1016/j.apsusc.2007.09.104.

[4] Kim H, Horwitz J. S, Kushto G. P, Kafa Z. H, Chrisey D. B, Indium tin oxide thin films grown on flexible plastic substrates by pulsed-laser deposition for organic light-emitting diodes. Appl. Phys. Lett. 2001 ; 79: 284-286. DOI: 10.1063/1.1350595.

[5] Hung-Chun H, Basheer L. T, Kuznetsov V. L, Egdell R. G, Jacobs R. M. J, Pepper M, and Edwards P.P, Dopant-induced bandgap shift in Al-doped $\mathrm{ZnO}$ thin films prepared by spray pyrolysis. J. Appl. Phys. 2012;112:083708. DOI:/10.1063/1.4759208.

[6] Sivasankar G, Ramajothi J, Aluminium Doped Zinc Oxide (ZnO) Thin Film Fabricated for Semiconductor by Spray Pyrolysis Technique. International Journal of ChemTech Research. 2015; 8:11: 497-501. http://sphinxsai.com/2015/ch_vol8_no11/2/(497-501)V8N11CT.pdf.

[7] Gungor E, Gungor T, Effect of the substrate movement on the optical properties of ZnO thin films deposited by ultrasonic spray pyrolysis, Advances in Materials Science and Engineering. 2012;1-7 Article ID 594971. DOI: 10.1155/2012/594971.

[8] Birgin E. G, Chambouleyron I, and Martinez J. M, Estimation of optical constants of thin films using unconstrained optimization. Journal of Computational Physics. 1999; 151: 862-888.

[9] Swanepoel R, Determination of the thickness and optical constants of amorphous silicon Journal of Physics E: Scientific Instruments. 1983; 16:12: 1214-1222. DOI:10.1088/0022-3735/16/12/023

[10] E. Gungor, T. Gungor, D. Caliskan, A, Ceylan, and E. Ozbay, Applied Surface Science, 318, 309-313 (2014). DOI:10.1016/j.apsusc.2014.06.132.

[11] Lee J. H, Park B. O, Characteristics of Al-doped ZnO thin films obtained by ultrasonic spray pyrolysis: effects of Al doping and an annealing treatment. Materials Science and Engineering: B 200415 February 2004; 106:3, 242-245. DOI:10.1016/j.mseb.2003.09.040.

[12] Pankove J. I, Optical processes in semiconductors, (Dover Publications, Inc. NewYork, 1975) p. 91. 


\title{
Türkçe Öz ve Anahtar Kelimeler ZnO İnce Filmlerinin Elektriksel ve Optik Özellikleri Üzerine Alüminyum Derişiminin Etkisi
}

\author{
Ebru Gungor ve Tayyar Gungor
}

Öz: Al:ZnO ince filmleri, farklı Al derişimlerine sahip olacak şekilde, bir sol-jel tekniği kullanılarak cam substratlar üzerine kaplanmıştır. Al aşılamasının Al:ZnO'nun yapısal, optik ve elektrik özelliklerine etkileri $\mathrm{XRD}$, optik geçirgenlik ve tabaka direnç ölçümleri ile incelenmiştir. Çinko asetatın derişimi 0,1 M olarak belirlenmiştir. İlk çözeltideki Al içeriği molarite aralığı bakımından $\% 0$ ile 20 arasında tutulmuştur. Film/Cam biçimindeki filmlerin optik geçirgenlik spektrumları, film kalınlığı ve optik bant aralığını bulmak için kullanılmıştır. Al:ZnO ince filmlerinin optik geçirgenlikleri görünür ve yakın kızılötesi bölgede \%80'den daha yüksektir. Al:ZnO filmlerinin optik bant aralığı, Al içeriğinin artmasıyla azalmaktadır. Filmlerin ortalama tabaka direncini elde etmek için, dört noktalı prob yöntemi ile beş farklı konumdan akım ve gerilim değerleri ölçülmüştür. Sonuçlara göre Al:ZnO ince filmlerinin tabaka dirençleri Al derişimi ile artmaktadır. Film kalınlığı ve geometric faktörler düşünüldüğünde, elektriksel direnç değerleri hesaplanmıştır. AZO filmlerinin, başlangıç çözeltisinde \%10 Al molaritesine kadar olan kısmında tabaka direncinin yükseldiği gözlenmiştir.

Anahtar kelimeler: Alüminyum aşılı çinko oksit; ince film; ultrasonik püskürtme pirolizi tekniği; elektriksel karakterizasyon; optik sabitler.

Sunulma: 09 Temmuz 2016. Düzeltme: 23 Eylül 2016. Kabul: 03 Ekim 2016. 